\title{
Impact of Management Practices in Industries in the Industrial - Free - Trade Zones in Douala, Littoral Region of Cameroon: "Challenges and Prospects"
}

\author{
Fuamenya A. Francis ${ }^{1}$ Ph. D, CNA \\ ${ }^{1}$ Department of Economics and Managent, University of Buea, Buea, Cameroon. \\ Correspondence: Fuamenya A. Francis, Ph. D, CAN, Department of Economics and Managent, University of Buea, \\ Buea, Cameroon.
}

Received: July 1, 2018

Accepted: September 4, 2018

Online Published: September 18, 2018

doi:10.5430/bmr.v7n3p10

URL: https://doi.org/10.5430/bmr.v7n3p10

\begin{abstract}
In Cameroon of late, there is growing consciencious that the deleterious impacts of industrial activities on safety health and environmental quality has motivated government and industries to adopt environmental management practices such as the EMSs and EMA, that is, Environmental Management Systems, and Environmental Management Accounting respectively at the least. This paper however, examines the implementation of EMSs and EMA amongst others in industries in the Industrial -Free - Trade Zones of the South West and Littoral Regions of Cameroon that interact with its environment which has been affected by the effluents emanating from industrial activities.

This paper also presents an overview of various initiatives like policies that have been crafted by the government of Cameroon to address the problems of industrial activity such as pollution etc. It also seeks to prescrible recommendations which could be used to save the regions, from industrial pollution. After the participation of Cameroon in the Earth's Summit in Rio de Janerio, Brazil (1992), and ever since the publication of the Brunditland Commission's Landmark Report 'Our Common Future', in (1987), the government has taken significant steps to overhaul its institutional framework vis - à - vis the regulation of industrial pollution.

Through a questionnaire based survey carried but from January to July 2016 with the sampled industries in the Industrial - Free - Trade - Zones of the South West and Littoral Regions of Cameroon, data was collected. This paper also aims at addressing motivational factors, implementation hurdles as well as benefits accrued by these industries as a result of adapting environmental management systems in their management practices generally. Studies also support that many benefits arise as a result of EMSs and EMA enforcement, but the paradox is the plethora of hurdles that still persist in industries. Against this background, this paper concludes by prescribing recommendations that seek to promote management practices such as EMSs and EMA in industries in Industrial Free - Trade - Zones in Cameroon.
\end{abstract}

Keywords: management practices, industrial - free - trade zones, challenges, prospects

\section{Introduction}

The Brundtland Report, WCED (1987) highlights the need for industries to show accountability and transparency in functioning and should be held accountable for their adverse impacts on the environment and as such offers a vision for economic growth and sustainable development that is, meeting the needs of the present without jeopardizing the requirements of future generations. That can be achieved through improved environmental management practices and Socio - economic performance; generally, there exist an array of different tools for the purpose of making industries more environmentally friendly and proactive. These tools are important because they have the ability to provide an industry with information pertaining to the prevailing environmental work and therefore, provide a robust underpinning for corporate environmental decision - making processes.

However, scholars like Emilsson and Hjilm (2002) explain, substance - flow - analysis, strategies environmental assessments, life - cycle assessment, and environmental management systems (EMSs) are just but a few of such tools available for attainment of these goals. 
In management practices, like EMSs, or EMA review reports, and other environmental management processes work via a network of management actions, procedures, documentations and records and is designed with the aim of promoting continous environmental improvements, Hilson and Nayee (2002) with ISO14001 as the international standard benchmark for environmental management practices, they all submit that corporate, environmental policies should address environmental goals of the industry, mission, vision, regulations, legal compliance, communication and education and environmental review audits and reports.

Moreover, under the auspices of the UNIDO, that is, the United Nations Industrial Development Organisation for the Gulf of Guinea large marine, Ecosystem Project aimed at safety health sustainance, treatment of industrial wastes, oil spills, sewage and heavy metals implementation. This paper argues that industrial activities in Cameroon have had little or no discernable impacts and therefore, greatly needs concerted attaintion from players, government and industries at the least, since they pose continous threat to safety, health and environment. In addition, this paper concludes that major environmental improvements can be attained where (i) competent staff are hired for controls against environmental industrial pollution (ii) research partnerships in academics (iii) industrial equipment standardisation (iv) institutional conflicts, cheeks (v) co-operation collaborative action and (vi) instituting appropriate controls. More benefits include:

- Improving environmental management performance of industries,

- Facilitating trade and removing trade barriers,

- Installing a culture of environmental responsibility in industries,

- Cost savings for industries via more efficient resource use and waste disposal costs reduction,

- Strategic business advantage in an increasinly competitive market.

\subsection{Presentation of Cameroon's Economy, Evolution and Environment}

Meanwhile, the macro environment of Cameroon can be captured through the presentation of its economic evolution and description of the main segments of the environment as technological, socio-cultural, economical, political and legal. Most scholars agree that economic evolution of Cameroon can be divided into three periods, Co-operational and Trade (2006), the first period generally qualified by the Authors as good start, ranged from 1965 to 1985 . The growth economy was driven by the exportation of farm products, i.e (beginning from 1965 - 1977), by the farm crops and crude oils from (1977 -1990). And the public income invested mostly in public investment and increased the standard of living of the government.

The second period qualified by Authors as the "crisis period" or the "fading hope period", ranged from 1985 to 1995. The causes included falling prices of crude oils and farm product, falling currency (local), and adjustment of public finance to reflect actual economic situation of the country. And lastly,

The third period was the structueral adjustment period, starting from 1993 and 1995 to early 2000s. To face the economic crisis, Government entered into negotiations with the international financial institutions like the IMF and World Bank to find a way out of the crisis. The measures agreed were the macro-economic reforms, the stabilization, Structural Adjustment Programmes (I, II \&III ) covering the period between 1983 to 2005. Therefore, sustaining accelerating improvements in industrialization means assured economic development for the nation.

Paradoxically, the pervasiveness of corruption also increases the cost of doing business in Cameroon. Also, Gauthiers (1997) reported that special payment to governmental officials during year represent almost one percent of the revenues of the surveyed companies. In the same vein, corruption, administrative bottlenecks, and fiscal pressures are among the hurdles for foreign direct investment in Cameroon. Macey J.R \& O'hara, M (2001), The World Bank (2006)

\subsection{Presenting Cameroon's Industrial Free-Trade-Zones as Case}

The study however, centers on sampled industries in the industrial Free - Trade Zones of Cameroon for investigations and improving understanding on their management practices. The problem identified is that the concept of the industrial - Free - Trade - Zones in Cameroon like in other countries in Africa and across the globe is increased competition among countries to attract scarce foreign direct investment for economic growth, that is, development via industrialization. That notwithstanding, studies show that while the Free - Trade - Zones in most countries have achieved their objectives for creation, those in Cameroon have conclusively failed. This study, therefore, seeks to find out why the Industrial -Free - Trade - Zones in Cameroon have not attained the goals. This investigation procedure involved a modified simple random sampling process for the selection of the needed samples, followed by a set of questionnaires and interviews aimed at collecting the required research data. Thereafter, an 
analysis of the data revealed that the environment of the Industrial Free - Trade - Zones in Cameroon were not friendly, that is, conducive to attract and support them attain the goals for which they were created. Going by the findings, the study recommend among others, that government should create an environment conducive to enhance the successful running, that is, operation of the industries in the industrial Free - Trade - Zones of Cameroon. They could also set goals that encourage management practices tos support and sustain those industries.

\subsection{Cameroon's Industrial Free - Trade - Zones' Perspectives}

What do we understand by industrial Free - Trade - Zones in Cameroon? The Industrial Free - Trade - Zones of Cameroon, otherwise Free - Zones elsewhere across the globe are identical in the common essential characteristics they possess. Thatnotwithstanding, the meaning of Free - Trade - Zones underscores that acceptable blue print proposed to provide state direct surrender over land ownership rights and usage by economic investors that lead to positive growth outcomes supporting development, that is, comparative attractiveness to investment. Because of the complexities in communities, societies and economies, the actual definition of the Free - Trade - Zone differs across countries of the planet earth but building on its fundamental goals at creation.

1.4 Cameroon's Industrial Free - Trade - Zone Act of the Republic of Cameroon describes it as a designated duty free area in which production and trade takes place. It also operates against the background of a wide range of incentives (trade), physical facilities and farms and other specialized economic activities. Merchandise, including services, may be brought into the Free - Trade - Zone duty free for manufacturing, processing, assembly, trading, bulk - breaking, repackaging, re-tabling or transshipment, for eventual and undirected export to international and domestic markets"' Government official Gazet, that is, Government's National Printing Press (1972, 1983). The objective of state decision here is to meet the challenge of development and also reinvigorate export process, manufacturing and support services such as trading, banking, insurance, communication etc. Numerous incentives were offered and are as detailed in the Investment charter of the Republic of Cameroon and annually highlighted in the Finance, Laws of Republic, decrees, provisions or legislation you name it.

\subsection{The Objectives of Cameroon's Industrial Free - Trade - Zones are:}

(i) To provide a conducive and enabling environment for direct foreign investment. And which outcome is the creation of employment and wealth.

(ii) To stimulate and enhance opportunities for growth in export trade of the non - oil and oil sectors, and generation of more foreign exchange earnings.

(iii) To provide the enabling environment for Cameroon's industrial development, and capacity, utilization via backward and forward linkages.

(iv) To stimulate and provide the conducive environment for the transfer of knowledge and technology to Cameroon.

(v) To provide a conducive environment for healthy competition in manufacturing in terms of quality and best business practices and thereby providing opportunities for products from the zones to compete favourably on the international market. Again, these objectives are far reaching and seek to assure industrial and economic development and why not the emerging Cameroon (2035) vision Agenda of Government.

\subsection{The Operational Area of Cameroon's Industrial Free - Trade - Zones}

This subsection briefly outlines the location of industries that make up the study area, notably on the coastline of Cameroon, in the bright of Bonny on the Gulf of Guinea, in the Congo Basin Rainforest. Douala is a city whose origin dates as far back as the end of the $15^{\text {th }}$ century, Mainet G. (1986). He also explains that it was at the end of the $19^{\text {th }}$ century that the city Douala, experienced veritable development as a commercial maritime - trading centre for slaves and tropical products. The present land use of Douala like elsewhere in Cameroon's Industrial - Zones on her coastline has evolved on the basis of its historical path, traced by a succession of European, nations' colonial past.

The urban legacy has been highly mirrored by the presence of the Germans up to 1945 and later, the French up to 1960. The zone covers areas including DOUALA (i.e. Bassa, Akwa and Bonaberi and Edea) all in the Littoral Region; Tiko and Limbe in the South West Region of Cameroon.

\section{1(ii) Cameroon's Industrial Free - Trade - Zones Aims and Activities.}

In Cameroon, notably in the Industrial Free - Trade - Zones in the South West and Littoral Regions, the industrial sector has made considerable contributions of socio -economic importance. The national industrial sector has some 
7,000 industrial units of which $80 \%$ are located in the Industrial Free - Trade - Zones of the South West and Littoral Regions of Cameroon.

Figure 1. Description of main industries in the Industrial Free Trade Zones within the Cameroon coastline, (Reproduced from Folack (1997)

Theindustries in these Regions are varied and include: Agro - Industrial companies, Food processing, Textiles and Accessories, Chemical and Mining, Building and Construction, Transportation, Materials, Paper and Pulp and Timberwood Processing (Angwe and Gabche, 1997).

According to the National Bureau of Statistics, Cameroon's industrial sector employed about 1.999,000 employees and paid out about US $\$ 799$ million annually in salaries. However, the industrial sector realized turnover of about US $\$ 9.999$ billion, Luken et al , (2002). This is an indication of the fundamental role played by the Cameroon's industrial sector, especially from an economic and social perspective.

Inspite of the socio - economic importance of the industrial sector in Cameroon's national economy, industrial pollutions like Aluminium emanating from industrial activities in the South West and Littoral Regions of Cameroon Seem to have inflected a wide range of complications to safety, health and environmental quality.

However, for example, long lasting exposure to significant concentrations of Aliminium can lead to serious health effects, such as damage to the central nervous system of population in the industrial zones etc.

2. Presenting the Characteristics of Industries in the Industrial Free - Trade - Zones of the South West and Littoral Regions of Cameroon

EMA and EMSs implementation in industries in the industrial free- trade -zones of the South West and litoral Region of Cameroon is driven by the understated characteristics of industries: 
Figure 1. Industrial Companies and Characteristics

\begin{tabular}{|c|c|}
\hline $\begin{array}{l}\text { Industrial } \\
\text { Companies }\end{array}$ & Characteristics \\
\hline A & $\begin{array}{l}\text { This is a chemical industry involved in the manufacture and distribution of chemical products } \\
\text { such as motor batteries. It employs about } 660 \text { people. }\end{array}$ \\
\hline B & This is an angro-industrial company. It manufactures rubber and employs about 360 people. \\
\hline $\mathrm{C}$ & This is a chemical factory that produces and distributes polypropylene sacks. It has 610 workers. \\
\hline $\mathrm{D}$ & $\begin{array}{l}\text { This company is involved in recycling of chemical products such as acid batteries. It employs } \\
220 \text { people. }\end{array}$ \\
\hline $\mathrm{E}$ & This is a food processing company. It processes vegetable oil and employs a total of 270people. \\
\hline $\mathrm{F}$ & This is an agro-industry that produces fruit juices. It employs about 560 people. \\
\hline G & $\begin{array}{l}\text { This is a chemical industry that manufactures and transport polythene bags. It has about } 398 \\
\text { workers. }\end{array}$ \\
\hline $\mathrm{H}$ & $\begin{array}{l}\text { This is a large petrochemical industry that is involve in emploration and refining of oil and gas. } \\
\text { It employs about } 689 \text { people. }\end{array}$ \\
\hline I & $\begin{array}{l}\text { The company is a food [rocessing industry. It processes milk products and employs about } 510 \\
\text { people. }\end{array}$ \\
\hline $\mathrm{J}$ & The company is into wood processing with 327 employees. \\
\hline $\mathrm{K}$ & This is a petrochemical industry. It employs about 300people \\
\hline $\mathrm{L}$ & $\begin{array}{l}\text { This chemical company is into soap and detergent production with a total of about } 625 \\
\text { employees. }\end{array}$ \\
\hline M & $\begin{array}{l}\text { It is a food processing industry. It brews beer and other soif drinks and employs more than } 700 \\
\text { people. }\end{array}$ \\
\hline $\mathrm{N}$ & $\begin{array}{l}\text { This company produces and markets electricity throughout Cameroon. It has over } 460 \\
\text { employees }\end{array}$ \\
\hline $\mathrm{O}$ & $\begin{array}{l}\text { This is a chemical company that produces cement and other chemical products.it has about } 590 \\
\text { workers }\end{array}$ \\
\hline $\mathrm{P}$ & This company processes water and employs more than 6000 people \\
\hline Q & This company is into diverse manufacturing. It has about 770 employees \\
\hline
\end{tabular}

Figure 1. The characteristics of Industries in the industrial Free - Trade Zones of Cameroon, Folack (1997)

It is impressive to note that, for example, Southward flowing streams along the Atlantic coastline of Cameroon that take their rise from the Bassa Industrial Free - Trade - Zones on the coastline of Cameroon registered the highest degree of Aluminiun pollution between May and June 2001, Fongwe et al ... (2001). Meanwhile, the population of the Bassa Industrial Free - Trade - Zone that depends on the coastal streams for drinking water might have fallen pray to excessive Aluminium pollution emanating from industries of that ecosystem.

However, in collaboration with international agencies and non- governmental organisations, the government of Cameroon has taken important initiatives to curb industrial pollution. From examining the relevant literature, it is clear that the degree of effectiveness and efficiency of these efforts remain questionable. As such, the following fundamental questions are therefore, also addressed in this paper: (i) what impact have each major initiative had on industrial pollution? (ii) Are there any conflicts (sectoral) between different governmental regulators?(iii) Is there concerted effort to address industrial pollution? (iv) Do all areas of operations have equitable support and assistance?(v)Are management practices on EMA or EMSs elfective? Solutions to these questions are prerequisite to successfully mitigate industrial pollution by government of Cameroon and business managers and directors.

The purpose of this paper is to analyse a plothera of initiatives that have been formulated to date by the government of Cameroon to encourage managers and directors of industries to promote a reduction in industrial pollution with a view of prescribing robust recommendations that could be used to savage communities and environment from industrial pollution. 


\section{Methodology}

\subsection{Presentation Of the Research Deseign}

The research questions were used to investigate how and to what extent one set explained or predicted by another set of one or more variables can be explained or predicted by another set of one or more variables. Therefore, the research can be classified, rational according to Trochim (2001), predictive, according to Cozby (2004), and decsriptive, according to Zikmud (2003). This research design is a cross-sectional descriptive and correlational study.

This type of design was used because a descriptive and correlated is suited in describing actual behaviour and predicting future behaviour(Cozby, 2004).

Moreover, on the contrary, to most behavioural research, environmental management practices research examines naturally occuring phenomena in non-experimental samples (Hitt \& Hoskison) (1998).

In representing the operational definitions of the constructs and variable: Here, the environment contruct has been described as composed of three derived constructs: complexity, dynamism and munificence, Tan and Litschert (1994). Therefore, the three variables used to operationally measure the environmental construct in the study were; (a) environmental munificence, (b) environmental dynamism,(c)environmental management practices or systems in industries.

The variable, munificence was used to measure the importance and availability of resources controlled by different environmental elements. The variable, dynamism was also used to assess the variability and predictabity of the different segments of consideration for the environmental matters. And finally, the variable, complexity was utilized to capture the heterogenity and diversity within the segments to the environment under the local operationalisation context of industries in Cameroon.

The recourse to perceptual measures is also supported by Millez (1988), adding that the way directors and managers (environmental) perceive their operational environment as more important and relevant to decision making than actual measures of environment and are also expected to have the strongest association with business strategies (e.g on environmental management). Pess and Rasheed (1993) add that the firm's actions, such as executive, information accessibility gathering or decision making would benefit most from perceptual measures considered. Therefore the research was designed to use managers' perceptions to determine their strategic orientation in environmental management practices or systems in industries. Meanwhile, the performance variable was also measured through dimensions as return on considered assets, return on sales, and overall firm performance based on environmental friendly perceptions and strategic management practices (Dess and Robinson Fr. (1984). Chandler and Hanks (1993) also reported that the self-reporting of organizational environment and performance correlate with objective measures with a high degree of reliability.

Moreover, each demension of the environment is multi-demensional in nature according to Tan and Litschert (1994) who used the 7 point Likert - type on directors and their practices on strategic managements effects on environment of firms.

In referring to scholars like Trochim (2001) who listed important issues that need be considered and addressed through the sampling to the questionaires design to the date collection steps.

\subsection{Presentation and Discusions on the Collected Data}

The researchers relied on data collection steps used by prior environmental management research in emerging economies like Cameroon (Amoako-Gyampah and Boye, 2000). The survey was directed to the contact person most likely to be involved in and knoledgeable about environmental management practice or systems like directors, or managers (ie environmental). Data for the study were gathered and stored using the statistical package for social sciences software (SPSS). The aggregation of the multiple demensions to generate reduced variable followed. And the test of dimensionality of different scales used was done through exploratory factors analysis. The method of parameter determination was the principal component analysis and the Kaiser's Measure of Sampling Adequacy (MSA) in examining and reporting purposes. As reported by Tan (1983), values usually greater than 0,8 were considered good, and 0,5 was accepted but values less than 0,5 required remedial action. After data were reduced and the variables defined, the relaibility and internal consistency of the measurement scale of each construct was determined by calculating Cronbach's Alpha $(\alpha)$. Following Tan and Litschner (1984), a value of Cronbach's Alpha $(\alpha)$ around (0.7) was considered good, and a value between $(0,5$ and 0,7$)$ was considered adequate, and other statistical tools, the Chi square and the Regresion Analysis were also used. 


\subsection{Tecniques of Data Collection and Testing of Hypotheses}

The two major sources of data collection were the primary and secondary sources. The research population was defined to include all companies sampled as operating in the zones. It is interesting that the Douala industrial free trade zone accounts for about 130 of total companies in the study area.

The tests of the Research Hypotheses from the objectives of the study. Some of the hypotheses based on economic performance that is, they first, sought to establish if there was a relationship between conductive environment and management practices for the economic performance of the zones. The second and third hypotheses were concerned with effects of inadequate environmental management practices or systems vis-avis the economic performance of the zones. With the aid of computerized data applications, we are able to abtain the follwing results of the three hypotheses based on the economic performance of the industries in the zoness in relationship with their environmental management practices or environmental management accounting (EMA) Practices in the zones.

The Regression Analysis for the first hypothesis:

\begin{tabular}{|l|l|l|}
\hline$R$ & $\mathbf{R}^{2}$ & AdjR $^{2}$ \\
\hline $\mathbf{0 . 9 9}$ & $\mathbf{0 . 9 8}$ & $\mathbf{0 . 9 8}$ \\
\hline F & $\begin{array}{l}\text { Standard } \\
\text { error }\end{array}$ & \\
\hline 868.56 & $\mathbf{0 . 6 3 6}$ & \\
\hline T.Statistics & $\mathbf{2 6 4 . 1}$ & \\
\hline
\end{tabular}

The results on second and third hypotheses:

\begin{tabular}{|ll|l|}
\hline $\begin{array}{l}\text { Contingency } \\
(\mathrm{cc})\end{array}$ & Coefficient & $\mathbf{0 . 9 8 7}$ \\
\hline $\begin{array}{l}\text { Contingency } \\
(\mathrm{cc})\end{array}$ & Coefficient & $\mathbf{0 . 9 9 2}$ \\
\hline
\end{tabular}

\section{The Regressional Analysis:}

Shows that there is a very strong relationship between condusive environment on one hand, and the economic performance via environmentals management practices or systems and environmental management accounting (EMA) practices of the firms or industries in the free - trade zones on the other. This is supported by the coefficient of determination $(\mathrm{R} 2=0.98)$ as well as the other results that is $(\mathrm{F}=868.568)$ and $(\mathrm{T}=264.1)$ which calculated values far exceed their critical values in the tables of $95 \%$ level of confidence. This means that, the null hypothesis of the first hypothesis has been rejected and the alternative hypothesis accepted. And as such, suggesting that there is a strong positive relationship between conducive environment as defined on one hand, and the economie performance from environment management andenviroment accounting practices or systems of the Free - Trade Zones on the other hand. As indicated above, the calculated values of the contingency co-efficient in respect of the second and third hypotheses are very high that is $(0.987$ and 0.992$)$. This means that the null hypothesis of both the second and third hypotheses have been rejected and alternate hypotheses accepted at $95 \%$ level of confidence. This suggests the provision of adequate incentives on environmental management practices or enviroment management accounting systems for definite possitive effects on the overall performance (economic, physical and environmental) of the FreeTrade- Zones industries.

\section{The Description Of Certain Variables}

The description of certain variables retained is taken from the literature. It is from here that certain descriptive characteristies of the profile of the enviromental management accounting practices and management retain their relative position from training, Julien and marcherney (1988). The subjective variable using the scale of Likert on points translating the atitudes capable of influencing the behaviour of management with regards to their environmental management practices or systems such as EMSs and EMA, that is, Environmental management accounting practices. Also, following is the set that determines the attitude of management's non-usage of models or strategies that is relative to set of questions translating the idea of reliability and the pertinence of accounting information as an environmental accounting and management tool for performance. 
Questionnaiers: The questions charactrized the accounting and management practices e.g EMA and EMSs respecting the views of management content representing the variables of the study e.g performance (Economi or environmental).

\section{Data Analysis, Presentation and Results or Findings}

The Tables below indicates the level on which the listed components serve as drivers for the corporation's environmental system, 1 represents extremely low and 5 extremely high and using the like square model the following details on the overall results were gathered and accordingly represented as such for South West and Littoral Regions - Cameroon

Table 1. listed components that serve as drivers for the corporation's environmental system

\begin{tabular}{llllllll}
\hline S/N & Issues & \multicolumn{6}{c}{ Classification of variables (percentage of respondents) } \\
\hline & & $\mathbf{5}$ & $\mathbf{4}$ & $\mathbf{3}$ & $\mathbf{2}$ & $\mathbf{1}$ & Don't know \\
1 & Compliance with regulation & $10 \%$ & $15 \%$ & $60 \%$ & $13 \%$ & $2 \%$ & - \\
2 & Certification of international board & $12 \%$ & $18 \%$ & $60 \%$ & $6 \%$ & $4 \%$ & - \\
3 & Due diligence (legal ability) & $9 \%$ & $19 \%$ & $30 \%$ & $40 \%$ & $2 \%$ & $1 \%$ \\
4 & Corporate citizenship & $15 \%$ & $10 \%$ & $60 \%$ & $10 \%$ & $5 \%$ & - \\
5 & Management of business system & $20 \%$ & $10 \%$ & $60 \%$ & $5 \%$ & $4 \%$ & $1 \%$ \\
\hline
\end{tabular}

\section{Researches field survey (2015 - 2016)}

From the Table, it is observed that 20 percent of the industries give high priority to management of business system, 15 percent of the industries considered compliance with regulation and corporate citizenship as extremely high. 9 and 12 percent respectively considered certification of international board and due diligence with extremely high level. In general a majority of the industries selected the average level of priority (3) for the components of EMSs that serve as drivers.

As concerns the level of priority, the industries give to key themes of environmental information impact, Table 2 below shows the different degree accorded by the industries.

Table 2. Level of environmental priority, 2015/2016 on industries in South West and Littoral Regions of Cameroon

\begin{tabular}{|c|c|c|c|c|c|c|c|}
\hline \multirow[t]{2}{*}{$\mathbf{S} / \mathbf{N}$} & \multirow[t]{2}{*}{ Issues } & \multicolumn{2}{|c|}{$\begin{array}{l}\text { Classification } \\
\text { respondents) }\end{array}$} & \multirow{2}{*}{\begin{tabular}{|l|} 
of \\
3 \\
\end{tabular}} & \multirow{2}{*}{$\begin{array}{c}\text { variables } \\
2\end{array}$} & \multicolumn{2}{|c|}{ (percentage 0} \\
\hline & & 5 & 4 & & & 1 & Don't know \\
\hline 1 & Carbon credits and taxes & - & - & - & - & - & - \\
\hline 2 & Greenhouse gas/energy issues & $20 \%$ & $10 \%$ & $60 \%$ & $6 \%$ & $4 \%$ & - \\
\hline 3 & Consumption of materials, resources and energy & $100 \%$ & - & - & - & - & - \\
\hline 4 & $\begin{array}{l}\text { Percentage rate of recycled materials versus virgin } \\
\text { materials }\end{array}$ & $25 \%$ & $5 \%$ & $60 \%$ & $10 \%$ & - & - \\
\hline 5 & Communication & $100 \%$ & - & - & - & - & - \\
\hline 6 & Employee health & $100 \%$ & - & - & - & - & - \\
\hline 7 & Environmental liability & $10 \%$ & $80 \%$ & $5 \%$ & $5 \%$ & - & - \\
\hline 8 & Greenhouse gas liability & $30 \%$ & $5 \%$ & $60 \%$ & - & $5 \%$ & - \\
\hline 9 & Sustainability index & $15 \%$ & $80 \%$ & $5 \%$ & - & - & - \\
\hline 10 & Internal reporting to industry association & $13 \%$ & $80 \%$ & $5 \%$ & $2 \%$ & - & - \\
\hline 11 & Emission from vehicles & $19 \%$ & $11 \%$ & $60 \%$ & $6 \%$ & $4 \%$ & - \\
\hline 12 & Limits on emissions & $21 \%$ & $8 \%$ & $60 \%$ & $6 \%$ & $5 \%$ & - \\
\hline 13 & Show improvements in performance & $18 \%$ & $12 \%$ & $60 \%$ & $8 \%$ & $2 \%$ & - \\
\hline 14 & Through environmental reporting & & & & & & \\
\hline
\end{tabular}

Researche's field survey (2015- 2016) 
From the table above it is observed that carbon credits and taxes seem not to be considered by the industries when dealing with issues of environmental priority. However, all the industries gave extremely high priority to the consumption of material, resources and energy; communication and employee health. Other aspects such as the environmental liability, sustainability index and internal reporting to industry association were given high priorities. A smaller portion of the industries, 5 percent or lower accorded extremely low priority to the items listed on the items listed on the table.

Looking at the level of current and future importance of some of the environmental issues, table 3 gives the level of importance attached to each of the environmental issues; where (1) is extremely low importance and (5) extremely high importance.

Table 3. Level of Present and Future environmental importance 2015/2016 on industries in the South West and Littoral Regions of Cameroon

\begin{tabular}{llllllll}
\hline S/N & Issues & \multicolumn{6}{c}{ Classification of variables (percentage of respondents) } \\
\hline & & $\mathbf{5}$ & $\mathbf{4}$ & $\mathbf{3}$ & $\mathbf{2}$ & $\mathbf{1}$ & Don't know \\
\hline 1 & Waste water management & $10 \%$ & $80 \%$ & $5 \%$ & $5 \%$ & - & - \\
2 & Hazardous waste management & $10 \%$ & $80 \%$ & $5 \%$ & $5 \%$ & - & - \\
3 & Protection of biodiversity and landscape & $10 \%$ & $80 \%$ & $10 \%$ & - & - & - \\
4 & Protection of soil and ground water & $5 \%$ & $80 \%$ & $15 \%$ & - & - & - \\
5 & Surface water use and management & $10 \%$ & $80 \%$ & $10 \%$ & - & - & - \\
6 & Land management and development & $9 \%$ & $80 \%$ & $11 \%$ & - & - & - \\
7 & Damage from atmospheric and climatic & $10 \%$ & $80 \%$ & $5 \%$ & $5 \%$ & - & - \\
& conditions & & & & & & - \\
8 & Non- hazardous waste and management & $10 \%$ & $80 \%$ & $10 \%$ & - & - & - \\
9 & Protection of air quality & $10 \%$ & $80 \%$ & $10 \%$ & - & - & -
\end{tabular}

Researcher's fielf survey (2015/2016)

From the Table above it is observed that a majority of the industries ( 80 percent) gives high importance (4) to the level of present and future environmental issues for waste management, hazardous waste management, protection of biodiversity and landscape; protection of soil and ground water; suface water use and management; land management and development; damage from atmospheric and climatic conditions. A general observation therefore is that environmental issues are given high level of importance as against a very small propotion of (5\%).

\subsection{Production of Sustainability Reports}

This section indicates whether the organization discloses the information in its annual reports where "1" shows strongly disagrees and ' 5 "' shows strongly agree.

Table 4 below shows the disclosure of environmental information in annual reports for 2015/2016 
Table 4. Disclosure of its environmental information in Annual Reports 2015/2016 on industries in the South West and Littoral Regions of Cameroon

\begin{tabular}{|c|c|c|c|c|c|c|c|}
\hline $\mathbf{S} / \mathbf{N}$ & Issues & Classi & ation & variab & cent & of re & pondents) \\
\hline & & 5 & 4 & 3 & 2 & 1 & Don't know \\
\hline 1 & It's natural environment & $20 \%$ & $10 \%$ & $60 \%$ & $5 \%$ & $5 \%$ & - \\
\hline 2 & Environmental policy & $20 \%$ & $80 \%$ & - & - & - & - \\
\hline 3 & Environmental objectives & $20 \%$ & $80 \%$ & - & - & - & - \\
\hline 4 & $\begin{array}{l}\text { Measurable standards, enabling performance } \\
\text { achieved to be compared with objectives }\end{array}$ & $15 \%$ & $10 \%$ & $60 \%$ & $5 \%$ & $\begin{array}{l}10 \\
\%\end{array}$ & - \\
\hline 5 & $\begin{array}{l}\text { Whether there is a senior management with } \\
\text { social/environmental responsibility }\end{array}$ & $100 \%$ & - & - & - & - & - \\
\hline 6 & $\begin{array}{l}\text { Whether there is a member of senior } \\
\text { management with social/environmental } \\
\text { responsibility }\end{array}$ & $100 \%$ & - & - & - & - & - \\
\hline 7 & Environmental impacts and risk & $20 \%$ & $80 \%$ & - & - & - & - \\
\hline 8 & Negative aspects of environmental activities & $20 \%$ & $80 \%$ & - & - & - & - \\
\hline 9 & Qualitative non-financial information & $15 \%$ & $80 \%$ & $5 \%$ & - & - & - \\
\hline 10 & Financial environmental information & $15 \%$ & $80 \%$ & $5 \%$ & - & & \\
\hline
\end{tabular}

\section{Researcher's fielf survey (2015/2016)}

It is observed from the table that 100 percent of the industries strongly agree that the following items are disclosed in their annual reports: whether there is a senior management with social/environmental responsibility and whether there is a member of senior management with social/environmental responsibility. Only about 10 percent disagrees that it includes issues on natural environment on its annual reports, while 15 percent does not disclose measurable standards, enabling performance achieved to be compared with objectives. In general, it is observed that the industries agree that most of the components are included in their annual reports.

Concerning the disclosure of environmental objectives, Table 5 shows the level of agreement with the objectives disclosed.

Table 5. Disclosure of environmental objectives, 2015/2016 on industries in the South West and Littoral Regions of Cameroon

\begin{tabular}{|c|c|c|c|c|c|c|c|}
\hline $\mathbf{S} / \mathbf{N}$ & Issues & \multicolumn{6}{|c|}{ Classification of variables (percentage of respondents) } \\
\hline & & 5 & 4 & 3 & 2 & 1 & $\begin{array}{l}\text { Don't } \\
\text { know }\end{array}$ \\
\hline 1 & Emission levels & $20 \%$ & $80 \%$ & - & - & - & - \\
\hline 2 & Pollution & $20 \%$ & $80 \%$ & - & - & - & - \\
\hline 3 & $\begin{array}{l}\text { Energy } \\
\text { consumption }\end{array}$ & $20 \%$ & $80 \%$ & - & - & - & - \\
\hline 4 & Noise levels & $15 \%$ & $60 \%$ & $10 \%$ & $5 \%$ & - & - \\
\hline 5 & Waste production & $15 \%$ & $80 \%$ & $5 \%$ & - & - & - \\
\hline 6 & Recycling & $20 \%$ & $60 \%$ & $19 \%$ & $1 \%$ & - & - \\
\hline
\end{tabular}

\section{Researcher's fielf survey (2015/2016)}

Table 5 shows that in terms of objectives; a majority of the industries ( 80 percent) agree that objectives such as emission levels, pollution, energy consumption and waste production are included in their annual reports, while 60 percent are indifferent on the inclusion of objectives such as noise levels and recycling. A very small proportion, 5 and 1 percent disagrees on the inclusion of noise levels and recycling respectively, as objectives on their annual reports. 
In terms of disclosure with respect to environmental expenditure, Table 6 indicates the various environmental expenditure components included in annual reports.

Tabl 6. Environmental expenditure 2015/2016 on industries in the South West and Littoral Regions of Cameroon

\begin{tabular}{|c|c|c|c|c|c|c|c|}
\hline \multirow[t]{2}{*}{$\mathbf{S} / \mathbf{N}$} & \multirow[t]{2}{*}{ Issues } & \multicolumn{2}{|c|}{$\begin{array}{l}\text { Classification } \\
\text { respondents) }\end{array}$} & \multirow{2}{*}{\begin{tabular}{|c|} 
of \\
3
\end{tabular}} & \multirow{2}{*}{$\begin{array}{c}\text { variables } \\
2\end{array}$} & \multicolumn{2}{|c|}{ (percentage } \\
\hline & & 5 & 4 & & & 1 & $\begin{array}{l}\text { Don't } \\
\text { know }\end{array}$ \\
\hline 1 & $\begin{array}{l}\text { Operating } \\
\text { expenditure }\end{array}$ & $20 \%$ & $80 \%$ & - & - & - & - \\
\hline 2 & Capital expenditure & $20 \%$ & $80 \%$ & - & - & - & - \\
\hline 3 & Reserves & $30 \%$ & $40 \%$ & $15 \%$ & $9 \%$ & $6 \%$ & - \\
\hline 4 & Liabilities & - & $10 \%$ & $10 \%$ & $80 \%$ & - & - \\
\hline 5 & Contingent liabilities & $24 \%$ & $16 \%$ & $60 \%$ & - & - & - \\
\hline
\end{tabular}

\section{Researcher's fielf survey (2015/2016)}

The Table above shows that most of the industries, 80 percent and above disclose expenditure on environmental operating expenditure and capital expenditure; 80 percent disagrees to the inclusion of expenditure on environmental liabilities.

As concern whether the organization identifies and discloses waste disposal, emission treatment and remediation cost bases on expenditure, table 7 give the level of agreement identification of each of this component.

Table 7. Waste disposal and remediation cost 2015/2016 on industries in the south west and litoral regions of Cameroon

\begin{tabular}{|c|c|c|c|c|c|c|c|}
\hline S/NO & ISSUES & $\begin{array}{l}\text { Class } \\
\text { respc }\end{array}$ & $\begin{array}{l}\text { icatio } \\
\text { dent) }\end{array}$ & of & arial & es & rcentage of \\
\hline 1 & Weight/mas of materials used & 5 & 4 & 3 & 2 & 1 & Don »know \\
\hline 2 & Treatment and disposal of waste & $15 \%$ & $9 \%$ & $60 \%$ & $6 \%$ & $19 \%$ & - \\
\hline 3 & Treatment of emission(expenditure on filterts,agent) & $15 \%$ & $80 \%$ & $5 \%$ & - & - & - \\
\hline 4 & $\begin{array}{l}\text { Expenditure on the purchasing and use of emisions } \\
\text { certificates }\end{array}$ & - & - & - & -- & - & - \\
\hline 5 & $\begin{array}{l}\text { Depreciation of related equipment,maintenance and } \\
\text { operating materials and service related staff cost }\end{array}$ & $15 \%$ & $20 \%$ & $60 \%$ & $5 \%$ & - & - \\
\hline 6 & Insurance for enviromental liability & - & - & - & - & - & - \\
\hline 7 & Clean-up cost,including cost for remediation of spills & - & - & - & - & - & - \\
\hline
\end{tabular}

\section{Reseacher field survey (2015-2016)}

The table shows that most of the industries (95 percent)at least agree for disclosing information on treatment of emissions. All of the industries do not disclose insurance for environmental liability; expenditure on the purchase and use of emission certificates and clean up cost. Whether or not they discloe weight of materials used,treatment and disposal of waste, many of the industries were indiffernt.

As concerns whether the corporation identifies and discloses prevention and environmental management cost based on expenditure related items, Table 8 below summarizes the level of agreement for each items considered below: 
Table 8. Environmental management costs 2015/2016 on industries in the south west and litoral Regions of Cameroon

\begin{tabular}{|c|c|c|c|c|c|c|c|}
\hline \multirow[t]{2}{*}{$\mathbf{S} / \mathbf{N}$} & \multirow[t]{2}{*}{ Issues } & \multicolumn{3}{|c|}{$\begin{array}{l}\text { Classification Of } \\
\text { RESPONDENTS) }\end{array}$} & \multirow{2}{*}{$\begin{array}{c}\text { Variable } \\
2\end{array}$} & \multicolumn{2}{|c|}{ (Percentage OF } \\
\hline & & 5 & 4 & 3 & & 1 & DON'T Know \\
\hline 1 & Weight/mass of material used & $15 \%$ & $80 \%$ & $4 \%$ & $1 \%$ & - & - \\
\hline 2 & Staff for education and training & $16 \%$ & $15 \%$ & $60 \%$ & $9 \%$ & - & - \\
\hline 3 & $\begin{array}{l}\text { external services of environmental } \\
\text { management }\end{array}$ & $15 \%$ & $80 \%$ & $2 \%$ & $3 \%$ & - & - \\
\hline 4 & $\begin{array}{l}\text { External certification of management } \\
\text { System }\end{array}$ & $10 \%$ & $21 \%$ & $60 \%$ & $3 \%$ & $6 \%$ & - \\
\hline 5 & $\begin{array}{l}\text { Staff for general enviromental management } \\
\text { activities }\end{array}$ & $12 \%$ & $14 \%$ & $60 \%$ & $9 \%$ & $5 \%$ & - \\
\hline 6 & Research and development & $100 \%$ & - & - & - & - & - \\
\hline 7 & $\begin{array}{l}\text { Extra expenditure on the installation of } \\
\text { cleaner technologies }\end{array}$ & $10 \%$ & $18 \%$ & $60 \%$ & $3 \%$ & - & - \\
\hline 8 & Extra expenditure on green purcheses & $15 \%$ & $15 \%$ & $30 \%$ & $40 \%$ & $5 \%$ & - \\
\hline 9 & Other environm,ental management costs & $15 \%$ & $13 \%$ & $60 \%$ & $10 \%$ & $2 \%$ & - \\
\hline
\end{tabular}

\section{Researcher's fielf survey (2015/2016)}

The results from Table 8 indicate that all the companies strongly agree that information is disclosed on costs related to research and development, while at least $80 \%$ of firms agree that external services for environmetal management and mass of material used are disclosed in the annual reports. However, a majority of the industries are in diferent or disagree to the fact that they disclose staff for education and training expenditure ; staff for general environmental technologies.

Table 9 Below indicates whether the corpoation identifies and disclose environmental protection expenditure.

Table 9. Environmental expendirture 2015/2016 on industries inthe south west and litoral regions of Cameroon

\begin{tabular}{|c|c|c|c|c|c|c|c|}
\hline $\mathbf{S} / \mathbf{N}$ & ISSUE & $\begin{array}{l}\text { Clas } \\
\text { respc }\end{array}$ & $\begin{array}{l}\text { cation } \\
\text { lents) }\end{array}$ & & aria & & rcentage of \\
\hline & & 5 & 4 & 3 & 2 & 1 & Don 't know \\
\hline 1 & Waste disposal & $15 \%$ & $80 \%$ & $5 \%$ & - & - & - \\
\hline 2 & Emission treatment & $15 \%$ & $80 \%$ & $5 \%$ & - & - & - \\
\hline 3 & Remediation & $10 \%$ & $10 \%$ & $\begin{array}{l}60 \\
\%\end{array}$ & $\begin{array}{l}15 \\
\%\end{array}$ & $\begin{array}{l}15 \\
\%\end{array}$ & - \\
\hline 4 & Prevention & $15 \%$ & $80 \%$ & $5 \%$ & - & - & - \\
\hline 5 & $\begin{array}{l}\text { Emvironmental management } \\
\text { cost }\end{array}$ & $15 \%$ & $80 \%$ & $5 \%$ & - & - & - \\
\hline
\end{tabular}

\section{Researcher's field suvey (2015-2016)}

The results from Table 9 show that except for remediation expenditure where a majority of the industries were indifferent ; a majority of industries at least agree that enviromental protection expenditure related to waste disposal, emission treatment,environmental management costs and prevention are disclosed in the annual reports.

In terms of the level at which the organization discloes its operating expenditure the table summarizes the level ranging from extremely low(1) to extremely high (5) as in Table 10. 
Table 10. Operation expenditure 2015/2016 on industries in south west and litoral Region of Cameroon

\begin{tabular}{|c|c|c|c|c|c|c|c|}
\hline \multirow[t]{2}{*}{$\mathbf{S} / \mathbf{N}$} & \multirow[t]{2}{*}{ ISSUES } & \multicolumn{2}{|c|}{$\begin{array}{l}\text { Classification } \\
\text { respondents) }\end{array}$} & \multicolumn{2}{|c|}{ of variable } & \multicolumn{2}{|c|}{ (percentage of } \\
\hline & & 5 & 4 & 3 & 2 & 1 & Don't know \\
\hline 1 & L iquid 3effeuent treatment & $20 \%$ & $80 \%$ & - & - & - & - \\
\hline 2 & Waste gas and air treatment & $18 \%$ & $80 \%$ & $2 \%$ & - & - & - \\
\hline 3 & Pollution prevention & $15 \%$ & $80 \%$ & $5 \%$ & - & - & - \\
\hline 4 & Solid waste treatment & $15 \%$ & $80 \%$ & $5 \%$ & - & - & - \\
\hline 5 & $\begin{array}{l}\text { Analysis contyrole } \quad \text { and } \\
\text { compliance }\end{array}$ & $5 \%$ & $19 \%$ & $60 \%$ & $11 \%$ & 5 & - \\
\hline 6 & Remediation & $6 \%$ & $20 \%$ & $60 \%$ & $11 \%$ & 4 & - \\
\hline 7 & Recycling & $8 \%$ & $19 \%$ & $60 \%$ & $10 \%$ & 3 & - \\
\hline 8 & Research and development & $15 \%$ & $80 \%$ & $5 \%$ & - & - & - \\
\hline
\end{tabular}

\section{Researcher's fielf survey (2015/2016)}

The sumarized results from Table 10 indicate that a majority of the industries disclose information on liquid effuent treatment, waste gas and air treatment, pollution prevention, solid waste treatment and research and development at high levels. However, remediation, recycling and analysis contrôle and compliance are given low levels in the discosure of operation related.

Looking at the level at which the corporation discloses its capital expenditure on environmental related issues, Table 11 summarizes the information with the levels ranging from extremely low (1)to extremely high (5)

Table 11. Capital expenditure 2015/2016 on industries in the south west and litoral Regions of Cameroon

\begin{tabular}{|c|c|c|c|c|c|c|c|}
\hline $\mathbf{S} / \mathbf{N}$ & ISSUES & $\begin{array}{l}\text { Class } \\
\text { respo }\end{array}$ & $\begin{array}{l}\text { icatio } \\
\text { dents }\end{array}$ & of & variab & es & ercentage of \\
\hline & & 5 & 4 & 3 & 2 & 1 & Don't know \\
\hline 1 & Liquid effluent trteatment & $20 \%$ & $80 \%$ & - & - & - & - \\
\hline 2 & Waste gas and air treatment & $20 \%$ & $80 \%$ & - & - & - & - \\
\hline 3 & Pollution prevention & $20 \%$ & $80 \%$ & - & - & - & - \\
\hline 4 & Solid waste treatment & $20 \%$ & $80 \%$ & - & - & - & - \\
\hline 5 & $\begin{array}{l}\text { Analysis } \\
\text { compliance }\end{array}$ & $15 \%$ & $10 \%$ & $60 \%$ & $10 \%$ & $5 \%$ & - \\
\hline 6 & Remediation & $15 \%$ & $10 \%$ & $60 \%$ & $10 \%$ & $5 \%$ & - \\
\hline 7 & Recycling & $15 \%$ & $10 \%$ & $60 \%$ & $10 \%$ & $5 \%$ & - \\
\hline 8 & Research and development & $20 \%$ & $80 \%$ & - & - & - & - \\
\hline 9 & equipment & $20 \%$ & $80 \%$ & - & - & - & - \\
\hline
\end{tabular}

\section{Researcher's fielf survey (2015/2016)}

Just as was the case in Table 11 ; the majority of the companies ( 80 percent) give high priority to the disclosure of capital expenditure relating to liquid effluent treatment,waste gas and air treatment;pollution prevention; solid waste treatment ;research and development and equipment

As concerns analysis contrôle and compliance ; remediation and recycling, a majority of the industries(60percent) give low priority in disclosing their capital expenditure on these items.

In addition, the level at which the organization generates and records physical environmemtal information is summarized in Table 12 below. The level of disclosure ranges from extremely low (1) to extremely high(5) 
Table 12. Physical environmental information 2015/2016 on the industries in the south west and litoral Regions of Cameroon

\begin{tabular}{|c|c|c|c|c|c|c|c|}
\hline $\mathbf{S} / \mathbf{N}$ & Issues & $\begin{array}{l}\text { Clas } \\
\text { respe }\end{array}$ & ication & of & variab & & rcentage \\
\hline & & 5 & 4 & 3 & 2 & 1 & Don’t know \\
\hline 1 & Raw and auxi liary materials & $13 \%$ & $15 \%$ & $60 \%$ & $11 \%$ & $1 \%$ & - \\
\hline 2 & Packaging material & $14 \%$ & $80 \%$ & $4 \%$ & $2 \%$ & - & - \\
\hline 3 & Merchandise & $16 \%$ & $13 \%$ & $60 \%$ & $9 \%$ & $2 \%$ & - \\
\hline 4 & Operating materials & $16 \%$ & $80 \%$ & $3 \%$ & $1 \%$ & - & \\
\hline 5 & $\begin{array}{l}\text { Water(all energy used by an organization from } \\
\text { sources) }\end{array}$ & $15 \%$ & $80 \%$ & $4 \%$ & $1 \%$ & - & - \\
\hline 6 & Energy (e.g electricity,gas,coal fuel oil,water) & $17 \%$ & $80 \%$ & $3 \%$ & - & - & - \\
\hline 7 & Products including packaging & $16 \%$ & $80 \%$ & $4 \%$ & - & - & - \\
\hline 8 & By- products including packaging & $18 \%$ & $9 \%$ & $60 \%$ & $9 \%$ & $4 \%$ & - \\
\hline 9 & Solid waste (such as waste paper, plastic containers) & $16 \%$ & $80 \%$ & $4 \%$ & - & - & - \\
\hline 10 & Hazardous waste (in solid form,liquid form) & $23 \%$ & $17 \%$ & $13 \%$ & $40 \%$ & $7 \%$ & - \\
\hline 11 & Waste water & $19 \%$ & $80 \%$ & $1 \%$ & - & - & - \\
\hline 12 & Air emoission including radiatios,noise & $24 \%$ & $18 \%$ & $16 \%$ & $40 \%$ & $2 \%$ & - \\
\hline
\end{tabular}

\section{Researcher's fielf survey (2015/2016)}

The result from Table 12 show that most of the industries ( 80 percent or more) give priority to the disclosure of physical information relating to issues such as packaging materials ;operating materials ; water; energy ; l solid waste and waste water. However, a majority (more than 60 percent)give low priority to the disclosure of information related to raw and auxiliary materials ; merchandise; by - productsincluding packaging, hazardous waste and air emission including radiations and noise.

\section{Monetary information of environmemtal accounting in industries in Cameroon.}

The level at which the organization generates and records monetary environmental information is presented in Table 13 : the level ranges from extremely low (1) to extremely high (5).

Table 13. Monetary environmental information 2015/2016on industries in the south west and litoral Regions of Cameroon

\begin{tabular}{llllllll}
\hline S/N & Issues & \multicolumn{2}{l}{$\begin{array}{l}\text { Classification } \\
\text { respondents) }\end{array}$} & of & variable & (percentage & of \\
& & 5 & 4 & 3 & 2 & 1 & Don't know \\
\hline 1 & Material cost of product outputs & $19 \%$ & $80 \%$ & $1 \%$ & - & - & - \\
2 & Materiall cost of non-product outputs & $17 \%$ & $80 \%$ & $3 \%$ & - & - & - \\
3 & Waste and emission contrôle cost & $10 \%$ & $11 \%$ & $60 \%$ & $13 \%$ & $6 \%$ & - \\
4 & Prevention and other environmental management & $10 \%$ & $15 \%$ & $30 \%$ & $40 \%$ & $5 \%$ & - \\
& costs & & & & & & \\
5 & Research and development cost & $5 \%$ & $19 \%$ & $60 \%$ & $11 \%$ & $5 \%$ & - \\
6 & Less tangible cost & $14 \%$ & $12 \%$ & $24 \%$ & $40 \%$ & $10 \%$ & - \\
7 & Environmental operating expenditure & $16 \%$ & $10 \%$ & $15 \%$ & $40 \%$ & $9 \%$ & - \\
8 & Environmental capital expenditure & $18 \%$ & $14 \%$ & $8 \%$ & $40 \%$ & $20 \%$ & -
\end{tabular}

\section{Researcher's fielf survey (2015/2016)}

The information summarized in Table 13 indicate that most of the industries give high priority to the disclosure of monetary enviromental information relating to material cost of product output and non-product output. However ,a 
greater proportion of the industries do not give high priority to the disclosure of monetary environmental information relating to prevention and other environmental management costs ; less tangible cost environmental operating expenditure and enviromental capital expenditure.

\section{Data Analysis and Presentation of Results or Findings}

Monetary environmental information is generated on the following: material cost products output, and materials of non-product output. Limited money environmental information is generated from the following: waste and emission control costs, and research and development costs.

And finally, the accounting information system of the corporations have not yet been adapted to be able to capture the monetary environmental information in the following areas: prevention and other environmental program, are generated and recording in the following ways: as a $\mathrm{p}$ art of the cooperation management account system, separate from the general ledger system: by a free standing system, using data electronically transferred from the general ledger or management account system of the corporation.

\section{Findings, Conclusion and Recommendations}

Findings on $\mathrm{EMS}_{\mathrm{S}}$ and EMA practices for conclusion and recommendations are: From the presentation and analysis of data above we realize that firms in industries implement the internationally recommended regulations on environmental issues like the ISO $1400 \mathrm{I}_{\text {and }} \mathrm{EMS}_{\mathrm{S}}$ along the coast line of the southerns region of Cameroon (that is, from Kribi, Edea, Douala in the Littoral Region to Tiko and Limbe in the South West Region). This also accounts for competitive edge the corporations have over some of its competitors in the international market which don't comply with EMSs or EMAs. However, the environmental mission statement is timidly implemented and the corporations have not yet got an environmental value status. No adequate environmental policy that could guide the organization in accounting for environmental impact. It was fascinating to note that some industries along the polluted areas of a developing country like Cameroon are making efforts to embrace EMSs and EMA as a tool for corporate sustainability. However, it was discouraging indeed, to observe that the rate of EMSs and EMA uptake by a majority of industries was poor and less satisfactory. It is important to note as well the fact that the EMSs and EMA process in these industries was still at its embryonic stage. Against this background, we proffer the following suggestions:

(a) Stakeholders Interests. Innovations include how customers, investors and wider stakeholders perceive them. For example, a company in the beer industry controls its brands, product designs and the quality of production but the actual manufacturing is sub-contracted.

- This faith is not based on the historic cost of the assets and liabilities but on the reputation of the company to delivered consistent competitive advantage. The competition advantage can be assigned to intangible assists suck as brands, employee capabilities, management reputation and so on. Tradition accounting is still struggling with how to provide an objective financial valuation methodology for these intangible assists. Increasingly, analysts and investor are using data that is outside traditional accounting when valuing a company. Many of these are non-financial -like customer churn (retention and recruitment) rates. This guide provides examples of companies trying to communicate their own monetized measures.

(b) Financial Accounting and Sustainability Accounting Practices. when the financial accounting principles were being codified, the global environmental impacts of industrialize society were not a pressing issue. At that time, industry was considered socially responsible if it provided return on investment and platform for national economic growth.

- Now, however, there is a growing understanding of the global environmental, social and economic consequences of large-scale industrialization. The demands made on companies to demonstrate that they are socially responsible, are changing, the focused of economic progress is moving from development- economic growth - to sustainable development-economic, social and environmental improvement on a global scale. Traditional accounting was not designed for this purpose but is presently undergoing a transformation process whereby historical financial accounting data relates to the broader sustainability debate. The sustainability accounting examples in this study are part of that transformation.

- Making decisions for sustainability requires a broader perspective that draws on economic, social and environmental dimensions.

c) Management Benefits of Sustainability Accounting Practices. Sustainability accounting can be partially operated in an organisation, sustainability accounts provide a useful internal organization's .sustainability 
management accounts that provide a useful internal reporting tool to track progress towards sustainability goals . In particular, they can be used towards sustainability and show how effective these expenditures are by linking goals.

- Identify resource efficiency and cost-saving opportunities by routinely collecting information on environmental and social related expenditures and show how effective these expenditures are by linking them to financial benefits and environmental and social performances. Compare performance and identity best practices. Link improvements in sustainability performance with specific and identified financial opportunities.

- Highlight the social and environmental risks associated with current financial performance-using external cost as an indicator of risk. Identify which stakeholder relationship present the greatest social and environmental risks. Show how environmental and social external costs decline over time with commitment to sustainability.

d) Environmental Accounting (EA) Issues and Practices. In the light of the study the need to account for environmental matters by company is a very demanding challenge every company is faced with. Environmental impact information may not be quantified in accounting figures; they are rather hidden overhead accounts.

However, the need for EA was conceived in recognition of the limitations of conventional accounting approaches for management activities and decisions involving significant environmental costs and/or significant environmental consequences/impacts. For example, the following conventional accounting practice might contribute to the inadequate considerations of environmental costs in internal decision-making.

- The unintentional "hiding «of many environmental costs in overhead accounts back to process, products and process line. Inaccurate characterisation of environmental costs or "fixed «when they may actually be variable (vice-versa). Inaccurate accounting of volumes (and then costs) of waste raw material. The actual lack of inclusion of relevant and significant environmental costs in the accounting records at all. In order for the management of firms, for example, to successfully position the corporation for the future, they should begin by cultivating these seven seeds of environmental accounting:

- A sustainable enterprise's success is defined by how efficient it uses life sustaining flows, time and space to optimise value for stakeholder while enhancing unit sustaining life. In this sense its value creation and ultimately its success is measured by the extent to which the quality of life genuinely improves.

- Develop vital flows and relationships: environmental accounting (EA) as an organic lens and framework. Redefines an organisational management, accounting and economic development. It helps you to see and develop the vital flows and relationship needed to sustain your organisation within its environment. For instance, the environmental accounting lens widens the organisation's perspective from "cash flow «to "life flow «and from "accountability «to "shareholders"

- Based on the findings and conclusion the study also proposes the following as an attempt to help improve on environmental and social disclosure/reporting.

- Companies are encouraged to have good «green image since they will have a marketing advantage over. Their competitors if they are known to be environmentally friendly and socially clean. They by recycling their products, using less energy, less noon-renewable resources and product that are not harmful, to the environmental and easily be integrated

- When environmental management accounting is applied. Companies with good "green credential «will attract investor who approves the company on ethical grounds. Even though it may be costly in the short-run, the long term benefit outweighs the short term costs. They can improve their "green «image by using sustainable raw materials, using fuel efficient transport and inserting equipment in factories to reduce pollutions. By carrying out environmental and social report, it improves the community understanding of the business goal, and place in the society, for example, educating stake holders about its intention to improve its performance. Through these report the organisations acknowledge responsibility for the environment and the society.

- To reduce pollution. Polluter pay principle- the government can allocate pollution permits, which can be bought by firms, which pollutes leading to market environmentalism. Finally, there is emerging and increasing need for environmental disclosures in corporate reporting by stakeholders. it is advisable for the university authorities to introduce a programmes on environmental accounting to cater for this emerging additional need of stakeholders' public 


\section{References}

Amoako Gyampah .k , \& Boye .S. (2000). Operation Strategy in an Emerging Economy: The case of Ghanian Manufacturing Industry. Journal of Operations Management, (49-71).

Angwe .C .A . \& Gabche, C. E. (1997). Quantitative Estimation of Land -based sources of pollution to coastal and marine environment of the Republic of Cameroon RCFO, Limbe, 33, (20-11).

Brundtland Commissions landmark report, "Our Common Future (1987), Nov, 1987vol,9. Pp (15-22).

Chandler, G.N . \& Hanks, S .H. (1993). Measuring the Performance of Emerging businesses: A validation Study. Journal of Business Venturing, ( 8)1, 311-408, 2005.

Cozb y, M. \& Cocburn .I. M. (2004). Zikmud (2003), Untangling the Origins of Competitive Advantage. Strategic Management Journal, 21(10/11) pp (112-114). may 2005.

Dess, G.G. \& Rasheed. (1993). Brobenson (1984), Measuring Organizational Performance in Absence of Objective Measures: the case of Privately held and Conglomerate Business Unit. Strategic Management Journal, 5(3), 171-266.

Emilsson,S. \& Hjelm , O. (2002). Implementation of Standardized Environmental Management Systems in Swedish Local Authorities: reasons, expectations and some outcomes. Environmental science and Policy, (5), 443-448. https://doi.org/10.1016/S1462-9011(02)00090-4

Folack, J. (1997). Impact of Human Activities on River Resources in Cameroon Republic,“ African Inland Fisheries, Aquaculture and the Environment, FAO-Fishing New Books, Yaoundé, Republic of Cameroon, pp (15-25).

Fongwe et al (2001) \& Fomekong .J. (1999). Key Elements for the Investment charter and Industrial Policy, Ministry of Commercial and Industrial Development Yaoundé, Cameroon, (76-84).

Hilson, G. \& Hoskison. (1998). Environmental Management System Implementation in the Mining Industry: a key to Achieving Cleaning Production. International. Journal of Mineral Processing, (64), (19-41). https://doi.org/10.1111/1475-4959.00038

ISOs- International Organisation for Standardization. (1996). ENISO-1400/ (1996):Environment, Management Systems: Specifications with Guidance for use- Swedish standards Institute-Stockholm.

Hilson, G. \& Nayee.V. (2002). The Environmental Impact of small scale gold Mining Ghana: Problems and Solutions. the Geographical Journal, 168, (57-72).

Luo. Y. (1999), \& Luken et al. (2002). Environment-Strategy -Performance: Relations in small Businesses in China: A case of Township and Village Enterprises in Southern China. Journal of small Business Management, 37, $37-52$.

Miller .D. (1988). Relating Porter's Business Strategies to Environmental Structures: Analyses and Performance Implications. Strategic Management Journal, 31(2), 280-299.

Tan.J. \& Litschert. M. (1993). Perceived Environments, Strategic Orientation, Ownership Effects and Performance Implications in a Transition Economy: an Empirical Study in China, (222-249)2650.

Trochim.W.M.K . (2001). The Research Methods Knowledge Base (2nd Ed), pp.201-219, Atomic dog Publishing.

(UNIDO). (1999). the United Nations Industrial Organisation: Oben, P.M(1999), Final report on Plankton Survey in Cameroon in the Gulf of Guinea,vol.13.

UNIDO. (2002). Cameroon Rio+10 Assessment, UNIDO, Vienna, Austria vol.58.

World Bank. (1995). Findings of a Report, ( $\left.\mathrm{N}^{\circ} 44\right)$ on Environmental Economics in Africa: Towards Sustainable Development, 76-89.

World bank. (2006). Summary of Cameroon's Investment Climate Assessment, Note No 38369,Jan 12,2007. World Commission on Environment and Development (WCED), 1987, Oxford University Press: Oxford. 